\title{
Estuarine and oceanic microflagellate predation of actively growing bacteria: estimation by frequency of dividing-divided bacteria
}

\author{
Paul G. Davis* and John McN. Sieburth** \\ Graduate School of Oceanography, University of Rhode Island, Kingston, Rhode Island 02881, USA
}

\begin{abstract}
Rates of predation and clearance of heterotrophic microflagellates, isolated from estuarine and oceanic environments, were estimated using actively growing bacterial prey. In separate experiments, a significant relation (by linear regression) was found between bacterial growth rate and frequency of dividing-divided cells (FDDC) for a species of Vibrio. This relation allowed the estimation of flagellate predation rates on these bacteria by comparing net bacterial growth with expected growth, predicted by FDDC, relative to the enumerated flagellate populations. Cell measurements and counts also allowed the estimation of flagellate clearance rates. Results suggest that flagellates can effectively prey upon bacteria at environmental concentrations ranging from $10^{5}$ to $10^{7}$ bacteria $\mathrm{ml}^{-1}$ at average rates ranging from 30 to over 200 bacteria flagellate ${ }^{-1} h^{-1}$. Environmental concentrations of flagellates further suggest that they play a dominant role as bacterial grazers in marine plankton.
\end{abstract}

\section{INTRODUCTION}

Over the last several decades advances in microbiological techniques including epifluorescence microscopy have elevated our estimates of bacterial numbers and biomass in the marine plankton by over 2 orders of magnitude (Sieburth, 1979). Similarly, evidence is mounting for the role of heterotrophic bacterioplankton as a dynamic population (Andrews and Williams, 1971; Azam and Hodson, 1977; Hobbie and Rublee, 1977; Fuhrman and Azam 1980, 1982; Burney et al., 1981, 1982) involved in the remineralization of 'dissolved' organic matter originating from primary producers. The transfer of this secondary production to the higher levels of the food web, however, is dependent upon predators capable of consuming the bacteria at in situ concentrations. Evidence for predation of bacteria by metazoans in marine planktonic systems has been minimal or negative, and although larvaceans may trap some bacteria on their fine filter nets (King et al., 1980), they do not appear to consume quantities which could affect bacterial population dynamics. Protozoans are well known bacterivores, but

- SEAMOcean, Inc. P.O. Box 1627, Wheaton, Maryland 20902, USA.

- Addressee for reprint requests amoebae (and other sarcodines) and ciliates may have only minor roles as bacterial predators in the marine plankton due to relatively low abundance of amoebae (Davis et al., 1978) and ineffective ciliate predation at planktonic bacterial concentrations (Fenchel, 1980). Heterotrophic flagellates, however, are a major group of known bacterial phagotrophs (Haas and Webb, 1979; Kopylov et al., 1980; Fenchel, 1982a, b; Sherr et al., 1983) and have been observed in relatively high abundance in the marine plankton (Sorokin, 1979; Fenchel, 1982C; Davis and Sieburth, 1982, in prep.). Therefore, heterotrophic flagellates by implication appear to be the major predators of planktonic bacteria in aquatic ecosystems. In addition, considerable biomass of phototrophic cyanobacteria (Johnson and Sieburth, 1979) and chemotrophic bacteria such as the methane oxidizers (Sieburth et al., 1984) is available as bacterial prey for protozooplankton.

There exists some controversy over whether heterotrophic flagellates act as phagotrophs or osmotrophs, the latter having been suggested recently by Beers et al. (1975). Kopylov et al. (1980) have presented data suggesting significant osmotrophy as well as phagotrophy in the flagellate species, Parabodo attenuatus, in competition with bacteria, although methodological questions may limit data interpretation. However, Haas and Webb (1979) were unable to demonstrate any 
significant uptake of dissolved amino acids at low concentrations. Fenchel (1982a) has argued that at the low concentrations of organics found in seawater, uptake is diffusion limited and proportional to length of the cell, and therefore, flagellates should make poor competitors of the much smaller bacteria for organic uptake.

The purposes of this present study were twofold. The first was to develop a predictive relation between growth rate of a selected marine bacterial strain and frequency of its dividing cells; the second was to use this relation to estimate predation rates of heterotrophic marine microflagellates upon actively growing bacterial prey. Frequency of dividing cells was developed by Hagström et al. (1979) to estimate the in situ growth rates of mixed bacterial populations and has been further studied and utilized by Newell and Christian (1981), Christian et al. (1982), and Hanson et al. (1983).

Rates of flagellate predation for several species have been estimated previously by Daggett and Nerad (1982), Fenchel (1982b), and Sherr et al. (1983) using static bacterial populations. Kopylov et al. (1980) calculated similar predation rates for a single marine flagellate species, Parabodo attenuatus, using a growing bacterial population. In the present study, flagellate predation of an actively growing bacterial strain was estimated for a number of different flagellate species isolated from both oceanic and estuarine waters.

\section{MATERIALS AND METHODS}

Flagellate predators. Fourteen different isolates of bacterivorous microflagellates were used in predation experiments, half of which isolated from Narragansett Bay and half from the Sargasso Sea (Davis and Sieburth, in prep.). The species isolated from Narragansett Bay were Actinomonas mirabilis, Paraphysomonas imperforata, a species of Monas (2 isolates), Acanthoeopsis unguiculata, a species of Bodo and Pseudobodo tremulans. The species isolated from the Sargasso Sea were Pseudobodo tremulans (2 isolates), a species of Monas, a species of Oikomonas, Bodo celer, $B$. designis, and Rhynchomonas nasuta. The species of Actinomonas, Paraphysomonas, and Monas were all in the size range of 4 to $6 \mu \mathrm{m}$ cell diameter. The species of Acanthoeopsis had a cell diameter of 4 to $5 \mu \mathrm{m}$ within a 8 to $10 \mu \mathrm{m}$ diameter silica lorica. The Bodo sp. from Narragansett Bay was approximately $5 \times 3 \times 2 \mu \mathrm{m}$ rectangular shaped, and $B$. celer and $B$. designis were both about $7 \times 3 \mu \mathrm{m}$ tubular shaped. The flagellate Oikomonas was of 2 to $3 \mu \mathrm{m}$ diameter, and the flagellate Rhynchomonas was $5 \times 3 \mu \mathrm{m}$ tubular shaped.
Bacterial prey. Seven bacterial strains isolated from Narragansett Bay were initially tested for suitability for the predation experiments. Suitability required the determination of a significant linear relation between frequency of dividing-divided cells (FDDC) and growth rate as described below, and the ability to support actively growing bacterivorous flagellate populations. A species of Vibrio (Strain G1; Baxter and Sieburth, 1984) was used solely for the experiments as it met each of the criteria. The medium used for bacterial growth in all experiments was filtered natural seawater supplemented with $10 \mathrm{mg}$ glucose $1^{-1}, 10 \mathrm{mg}$ $\mathrm{NH}_{4} \mathrm{Cl} \mathrm{l}^{-1}$, and $1 \mathrm{mg} \mathrm{FePO} \mathrm{l}^{-1}$ and autoclaved prior to use. Narragansett Bay (NB) water was used for all experiments involving flagellates isolated from Narragansett Bay, and Sargasso Sea (SS) water was used with oceanic isolates. All experiments were conducted in $250 \mathrm{ml}$ of autoclaved media. Experiments were conducted at $21^{\circ} \mathrm{C}\left( \pm 1 \mathrm{C}^{\circ}\right)$ on an environmental shaker swirling the flasks at $100 \mathrm{rpm}$. Bacteria were preconditioned for all experiments by growing on fresh medium 24 to $48 \mathrm{~h}$ prior to inoculation.

Bacterial FDDC growth rate experiment. One ml of preconditioned bacterial culture (approximately $2 \times$ $10^{7}$ cells $\mathrm{ml}^{-1}$ ) was added to $200 \mathrm{ml}$ of sterile medium and sampled every $3 \mathrm{~h}$ for $24 \mathrm{~h}$ by withdrawing $10 \mathrm{ml}$ of culture and preserving with $0.5 \%$ (V/V) glutaraldehyde (final conc.). Three such successive experiments were performed with the bacterial culture subsequently used in the predation experiments: 2 with NB water, 1 with SS water as a medium base. Bacteria were enumerated by epifluorescence microscopy using the fluorochrome DAPI (Porter and Feig, 1980) and the frequency of dividing-divided cells (FDDC) was determined for all samples. The classification of a cell as a dividing-divided cell differed from the FDC (frequency of dividing cells) of Hagström et al. (1979) by including cells with complete separation, although such cells were included in the counts only if the separation was much smaller than the cell radius, and the cell orientation indicated recent division. This alteration of the procedure elevated the percentage of 'dividing' cells counted in a given sample (ranging from 13 to $38 \%$ of the total number of cells present) over FDC counts and, therefore, reduced the total number of bacteria necessary to be counted.

Predation experiments. Predation experiments were begun by adding $10 \mathrm{ml}$ of preconditioned bacterial culture (approximately $2 \times 10^{7}$ cells $\mathrm{ml}^{-1}$ ) and $1 \mathrm{ml}$ of a mature flagellate culture to $200 \mathrm{ml}$ of media. Thus, bacteria in the $1 \mathrm{ml}$ of flagellate culture (approximately $10^{7}$ bacteria $\mathrm{ml}^{-1}$ ) were considerably outnumbered by a bacterial strain preconditioned to a presumably lower nutrient medium (flagellate cultures were obtained and maintained on bacteria developing in a 
rice grain enrichment). Cultures were allowed to grow approximately $12 \mathrm{~h}$ prior to the first sampling to allow for initial growth of the flagellate and bacterial populations. Sampling was conducted as in the FDDCgrowth rate experiment but was performed at the beginning and end of a $3 \mathrm{~h}$ interval once per day for 4 to $5 \mathrm{~d}$, during which time flagellate populations grew to maximum densities.

After the final sampling, a second phase of the experiments was begun in which the cultures were diluted with fresh medium to examine flagellate predation rates at lower bacterial densities. The grown cultures were diluted with fresh medium at a ratio of $1: 5,1: 10$, and $1: 20$ for NB flagellates, and at $1: 4,1: 6$, and $1: 10$ for SS flagellates, since the latter generally achieved lower final flagellate densities. Two $\mathrm{ml}$ of preconditioned bacteria culture were added to each flask to reduce further the chance that other bacteria present in the initial flagellate culture would interfere with the experiments. Cultures were given an adjustment period of $2 \mathrm{~h}$ prior to sampling and 3 samples were taken at $3 \mathrm{~h}$ intervals. All samples were counted by epifluorescence microscopy for Protozoa by staining with acridine orange (Davis and Sieburth, 1982) and for bacteria and FDDC as noted above. Four of the 14 cultures of flagellates did not reach sufficient final cell densities to allow accurate counting at the dilutions used in the second stage of the experiments, and these data are not graphed.

Bacterial counts of control flasks in which $1 \mathrm{ml}$ of flagellate culture was inoculated without additional bacteria showed initial bacterial levels of less than $10^{5}$ bacteria $\mathrm{ml}^{-1}$ which grew to levels of $10^{6}$ to $5 \times 10^{6}$ bacteria $\mathrm{ml}^{-1}$ over a period of several days, after an initial lag period exceeding $6 \mathrm{~h}$. It is believed that the higher initial inoculation of the G1 bacteria (approximately $2 \times 10^{6} \mathrm{ml}^{-1}$ ) in the experimental flasks, as well as their more rapid growth rates on the low substrate media, easily allowed the dominance of the G1 bacteria over bacteria introduced with the flagellate. Examination of bacteria from the experimental flasks during counting always showed an overwhelming predominance of morphologically uniform bacteria.

Experimental calculations. In FDDC/growth rate experiments for bacterial cultures, a linear relation was tested by linear regression analysis between estimated FDDC values and growth rate calculated between each 2 successive samples in the experiments. Growth rate $\mathrm{u}=\left(\ln \mathrm{N}_{\mathrm{a}} / \mathrm{N}_{0}\right) / \mathrm{t}$, where $\mathrm{N}=$ number of bacteria $\mathrm{ml}^{-1}$ at times zero and $\mathrm{a}_{i}{ }^{\prime} \mathrm{t}$ ' $=$ time between samples $(3 \mathrm{~h})$. The FDDC value used for each paired observation was that value at time zero.

Using the linear regression developed between FDDC and ' $u$ ', the FDDC of the bacterial prey in the experimental flasks was used to estimate actual growth rates of the bacteria during predation by bacterivorous flagellates. This allows calculation of the bacteria consumed between successive sampling intervals by using formulas similar to those of King et al. (1980) and Kopylov et al. (1980). Since $N_{t}=N_{o} e^{(u-d) t}$ - where ' $\mathrm{u}$ ' = bacterial growth rate (as estimated by FDDC), ' $\mathrm{d}$ ' = grazing rate (both in the units $\mathrm{h}^{-1}$ ) $-\mathrm{d}=$ $\mathrm{u}-\left(\ln \mathrm{N}_{\mathrm{t}} / \mathrm{N}_{0}\right) / \mathrm{t}$. The number of bacteria grazed per hour is then equal to the grazing rate, times the average number of bacteria present during the sampling interval $(\bar{N})$, or $d \bar{N}=d\left(N_{t}-N_{o}\right) /\left(\ln N_{t} / N_{o}\right)$. Similarly, the average number of flagellates present during the sampling interval equals $\bar{X}=\left(X_{t}-X_{0}\right) /\left(\ln X_{t} / X_{o}\right)$, where ' $\mathrm{X}$ ' $=$ number of flagellates at times zero and ' $\mathrm{t}$ '. Therefore, the average number of bacteria consumed per flagellate per hour is calculated as $(\mathrm{d} \overline{\mathrm{N}}) / \overline{\mathrm{X}}$. Clearance rate was estimated as the average number of bacteria grazed per flagellate per hour $(\mathrm{d} \overline{\mathrm{N}}) / \overline{\mathrm{X}}$ divided by the average number of bacteria present during that sampling interval $(\overline{\mathrm{N}})$, or $d / \overline{\mathrm{X}}$. These calculations assume that $u(N)$ and $d\left(N_{1} X\right)$ are constant over a short time interval.

\section{RESULTS AND DISCUSSION}

\section{FDDC-growth rate experiments}

The results of experiments determining the relation between frequency of dividing-divided cells (FDDC) and bacterial growth rate for Vibrio strain G1 are shown in Fig. 1. Analysis by linear regression was highly significant $(\alpha<0.0001)$ and there was no significant difference between the use of Narragansett Bay or Sargasso Sea water as a medium base. The strength of this relation allows the prediction of growth

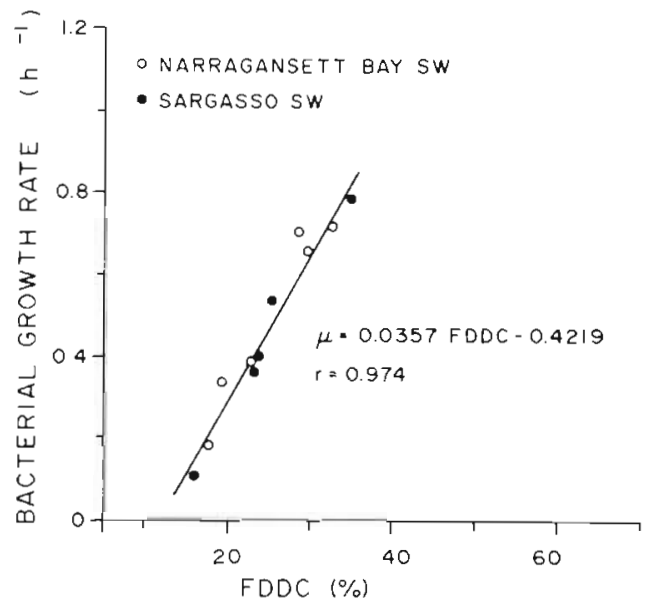

Fig. 1. Vibrio Strain G1. Relation between growth rate $(u)$ and 'frequency of dividing-divided cells' (FDDC) in batch culture, using Narragansett Bay and Sargasso Sea waters as media bases. Linear regression equation given, with correlation coefficient (r). Significance of regression, $\alpha<0.0005$ 
for this strain of Vibrio in the media over a 3 h sampling interval as conducted in these experiments. Prediction of growth rate does not require the knowledge of the time required for cell division as in the method used for phytoplankton (McDuff and Chisholm, 1982). The technique requires only that the population be continuously dividing at the specific growth rate over the sampling interval, and that the growth rate be linearly related to the FDDC of the initial sample.

Frequency of dividing cells as an index of growth has been used only recently for bacteria, primarily to estimate growth of environmental populations (Hagström et al., 1979; Christian et al., 1982; Larsson and Hagström, 1982; Hanson et al., 1983). FDDC as determined in the present study yielded significantly higher values (15 to $40 \%$ FDDC) than those measured for FDC by other authors. This is a result of the intentional inclusion of cells as dividing which had complete separation between cells, though only when it was obvious that the cells had recently undergone division, as discussed in the 'Methods' section. FDC for several samples in the present study counted by the method of Hagström et al. (1979) yielded values averaging $26.1 \%$ of the FDDC values obtained in the present study. It was felt that the increase in statistical accuracy from the larger number of dividing cells counted for a given number of bacteria was greater than the likelihood of mistakenly including cells which had not recently undergone division. This assumption is probably valid when working exclusively with a single bacterial strain rather than with mixed bacterial populations.

Another significant difference between the present use of FDDC and previous work on FDC is the estimation of FDDC and bacterial growth rates over several $3 \mathrm{~h}$ intervals within the growth curves. The growth rate of the G1 bacterial strain has been previously noted to change during its 'exponential' growth phase in batch culture (Baxter and Sieburth, 1984) and this observation was repeated several times during the present study. Exponential growth rates estimated between $3 \mathrm{~h}$ intervals, however, were found to be linearly related to FDDC and this fact allows prediction of bacterial growth in flagellate cultures over $3 \mathrm{~h}$ sampling intervals. The linear relation FDDC to growth rate broke down as the bacteria reached stationary phase in batch cultures, at a concentration of about $2 \times 10^{7} \mathrm{ml}^{-1}$; therefore, predation calculations were not made when bacterial concentrations were greater than $10^{7} \mathrm{ml}^{-1}$. FDDC values during stationary phase tended to be high for low or negative growth rates. While the slope of the line in Fig. 1 would suggest a positive FDDC for some negative growth rates, where bacterial death would exceed growth, FDDC values lower than $12 \%$ were not observed.
The strength of the FDDC to growth rate relation was further tested by examining the results of similar growth studies on the same bacterial strain using four different media: natural seawater alone or with glycerol, acetate, or casein added to concentrations of $10 \mathrm{mgl}^{-1}$. Bacterial growth rates as estimated by FDDC using the previously generated linear regression differed only slightly (average $3.5 \%$; standard deviation $2.9 \%$ ) from those calculated from the actual change in cell numbers over the $3 \mathrm{~h}$ intervals. Therefore, the relation of FDDC to growth rate may be expected to hold even as the concentration or type of available nutrients or substrate changes during the predation experiment, due to the influence of bacteria and flagellates.

Predation rates of flagellates on bacteria estimated by this method gave values ranging from 0 to 300 bacteria flagellate ${ }^{-1} \mathrm{~h}^{-1}$ over a range of bacterial concentrations of $10^{5}$ to $10^{7} \mathrm{ml}^{-1}$. These data are presented graphically in Fig. 2A-2E and 3A-3E for 10 of the flagellate cultures. Experiments for the 4 remaining flagellates tested (Actinomonas mirabilis, Acanthoeopsis unguiculata and the Sargasso Sea isolates of Monas sp. and Bodo celer) yielded four or fewer data points each (averaging 224, 136, 173, and 137 bacteria consumed $\mathrm{h}^{-1}$ flagellate ${ }^{-1}$, respectively) and their values are not shown graphically.

In 9 of 121 predation rate estimates, the values exceeded 500 bacteria $h^{-1}$ flagellate $^{-1}$; this greatly exceeds all other estimates and seems excessive from observations of flagellate feeding. In each case, these estimates were generated from samples taken early during the experiments when bacterial concentrations were close to $10^{7} \mathrm{ml}^{-1}$ and protozoan densities were low (about $10^{3} \mathrm{ml}^{-1}$ or less). The larger error in the protozoan counts due to fewer cells counted and the breakdown of the FDDC to growth rate relations at high bacterial densities probably contributed to the estimation of these high predation rates. They have not been included further in the data analysis since they are probably erroneous and would greatly skew the results.

Fenchel (1982b) estimated maximal predation rates of marine flagellates on non-growing bacteria for several of the same flagellate types and found values

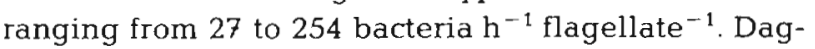
gett and Nerad (1982) estimated slightly lower rates (25 bacteria flagellate ${ }^{-1} \mathrm{~h}^{-1}$ ) for Bodo edax also using a static bacterial prey. In another study, predation rates of a Monas sp. on different bacterial species ranged from 10 to 75 bacteria consumed flagellate ${ }^{-1} \mathrm{~h}^{-1}$ (Sherr et al., 1983). These values fall within the range of predation rates estimated by the present study. Kopylov et al. (1980) calculated feeding rates for the flagellate species Parabodo attenuatus using formulas 


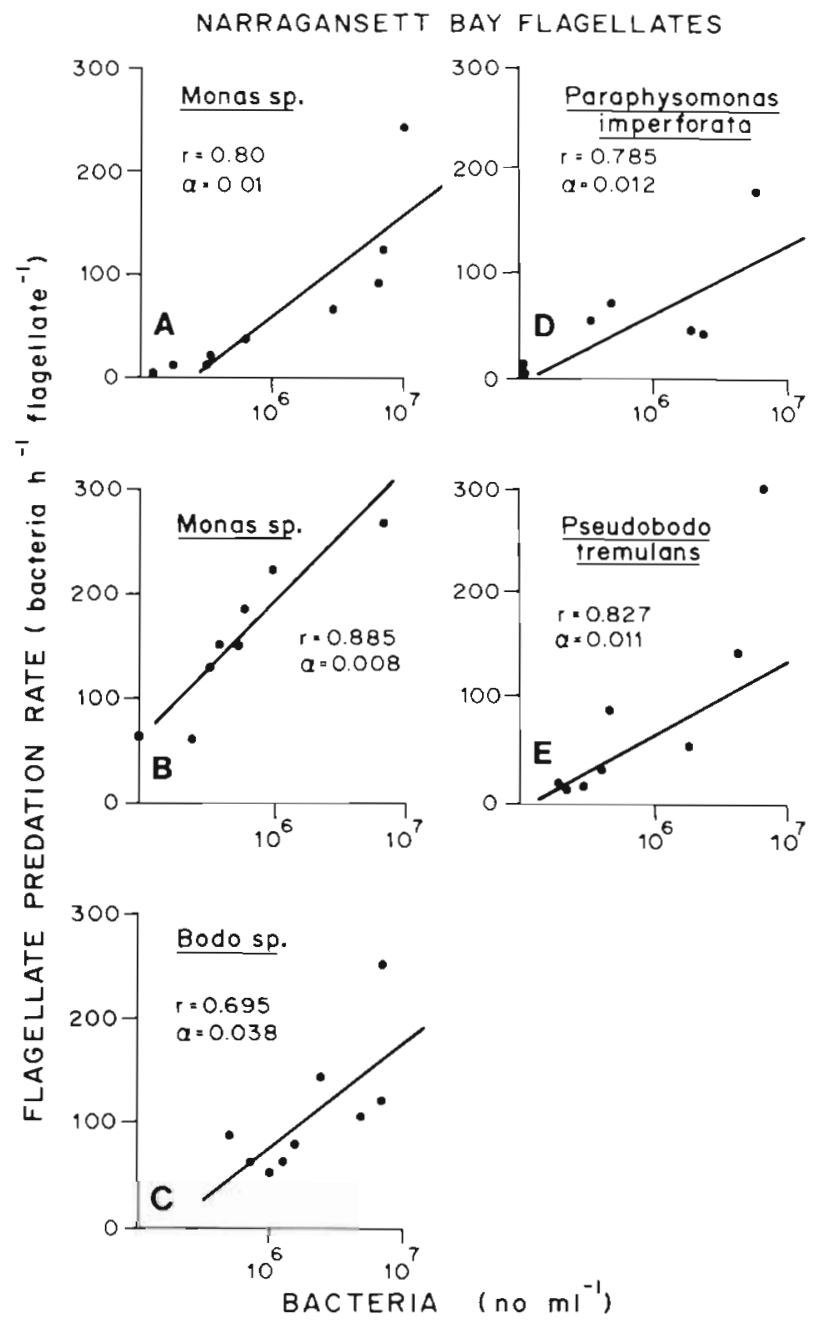

Fig. 2A-E. Plots of Narragansett Bay flagellate predation rates (bacteria consumed $\mathrm{h}^{-1}$ flagellate ${ }^{-1}$ ) vs. bacterial concentration (log scale) for each species of flagellate. Correlation coefficient $(r)$ and significance of regression $(\alpha)$ given for each plot

similar to those used in the present study. They found bacterial consumption ranging from 80 to 125 bacteria $\mathrm{h}^{-1}$ flagellate ${ }^{-1}$. Their data also suggest that uptake of dissolved organic matter may account for 20 to $30 \%$ of caloric intake. These data were generated by estimating bacteria growth rates and dissolved organic matter uptake in control flasks containing no flagellates, and, therefore, assumes that there is no effect of flagellate predation upon bacterial growth or activity, which seems unlikely. Such effects have been demonstrated by Kopylov and Moiseyev (1980), as well as by Sherr et al. (1982).

In general, the predation rates calculated in the present study show significant linear increases with log means of bacterial concentration (Fig. 2A-J; 3A-E). Fenchel $(1980,1982 b)$ has argued that predation rates should increase as a hyperbolic with prey concentra- tion and was able to fit his data to such curves to derive maximal rates of predation. The linear relation with log bacterial concentration in the present data suggests that the predation rate is approaching saturation. Sherr et al. (1983) reported a linear increase in predation rates of a Monas sp. with increasing bacterial density, and the effect of saturation is evidenced by their plot of clearance rate. The experiments of Sherr et al. (1983) were run at much higher bacterial concentrations, ranging from $2.5 \times 10^{7}$ to $8.5 \times 10^{8} \mathrm{cells} \mathrm{ml}^{-1}$.

The recognition of trophic strategies among the different flagellate species is critical to comprehending their functional roles in the marine plankton. For example, 2 general trophic strategies appear to exist for the different flagellate species frequently observed in the plankton: (1) predation by 'filtration' of bacteria from the medium, (2) predation of bacteria by 'direct encounter' during flagellate movement. Flagellates in

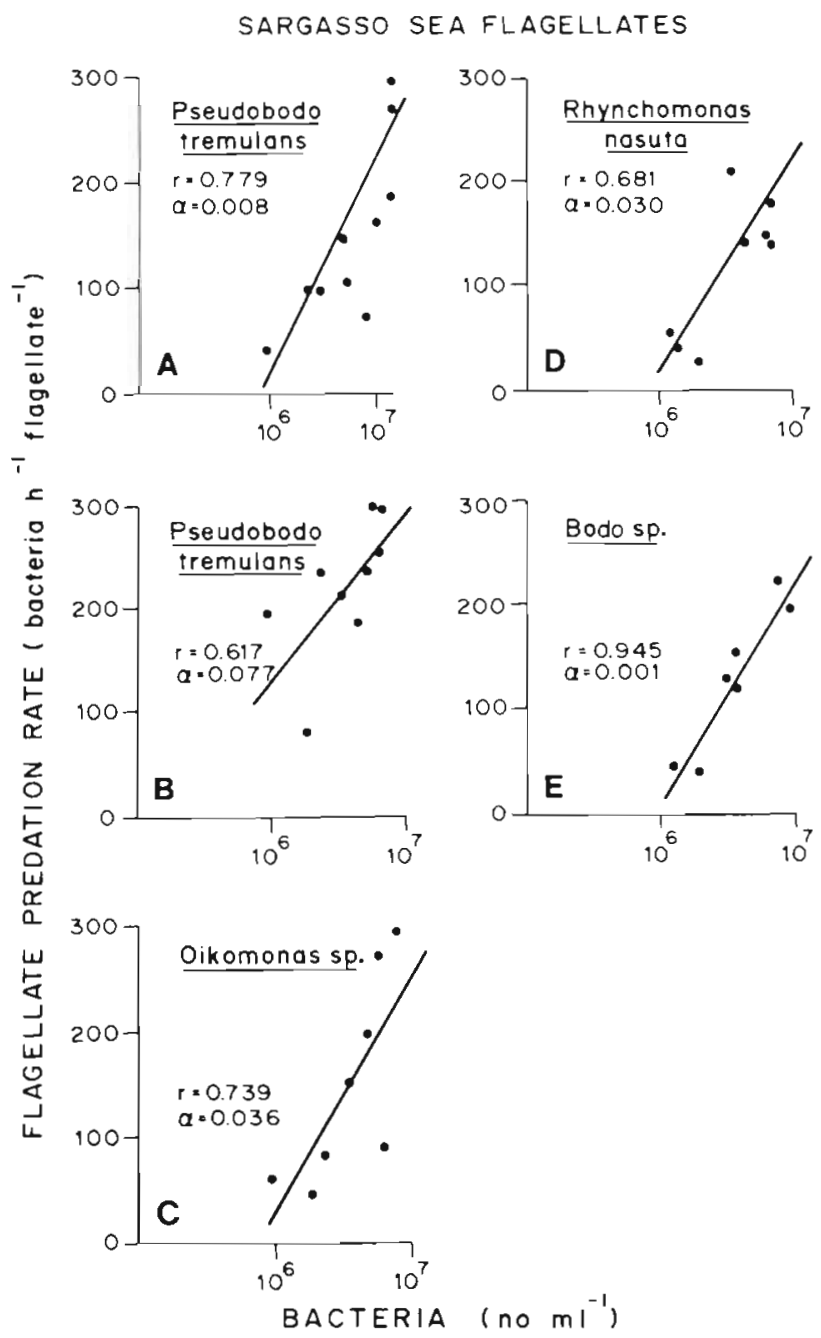

Fig. 3A-E. Plots of Sargasso Sea flagellate predation rates (bacteria consumed $\mathrm{h}^{-1}$ flagellate ${ }^{-1}$ ) vs. bacterial concentration (log scale) for each flagellate species. Correlation coefficient $(r)$ and significance of regression $(\alpha)$ given for each plot 
the 'filtering' category would include the choanoflagellates and chrysomonad-like flagellates such as the bicoecids and the genera Actinomonas, Paraphysomonas, Monas and Pseudobodo. These flagellates establish currents by flagellar action which pass water and bacterial prey over the cell surface, and the bacteria are captured by various mechanisms.

Most of the remaining bacterivorous microflagellates, primarily bodonids, would fall into the encounter-feeder' group: those which rely upon movement of the flagellate towards the bacterial prey. Flagellar motion in this case plays a much smaller role in the movement of distant bacterial prey to the cell surface. For the higher bacterial levels in the present experiments (greater than $4.0 \times 10^{6} \mathrm{ml}^{-1}$ ), predation rates of the 'filterers' were significantly higher than those of the 'encounter feeders' ( $\alpha=0.005$ Wilcoxin Rank Sum Test) averaging 204 and 156 bacteria $h^{-1}$ flagellate $^{-1}$, respectively. Such distinctions between flagellate types are of ecological importance since most microflagellates have a strong tendency to adhere to particles. 'Encounter-feeders' would more likely graze surface-adhering epibacteria whereas attached 'filterers' would continue to graze unattached planktonic bacteria. Flagellates which show no tendency toward attachment are rare, based on the strains cultured in concurrent studies (Davis, 1982). All flagellate isolates used in the present study, however, were chosen because the number of attaching cells in culture was low relative to non-attaching cells swimming free in the media. Caution should be used in selecting flagellate species for estimation of predation or clearance rates when only the free-swimming flagellates are measured. Attached flagellates may be dense relative to non-attached cells and possibly have a significant effect upon bacteria free in the medium. Predation rate estimates based on the disappearance of bacterial cells are over-estimated to the extent that flagellates attached to the experimental flask walls prey upon non-attached bacteria.

Fenchel (1982a) identifies 2 other trophic strategies which characterize the flagellates: flagellates may (1) sieve bacteria through projections of the cell membrane from the cell surface (e.g. species of Actinomonas, Monosiga), or (2) directly contact bacteria on their surface lacking such projections (e.g. bodonids, species of Monas and Pseudobodo). In the former category, the 'sieve' is essentially an adaptation which increases the cell surface area and thus increases the likelihood of cell contact and retention of bacterial prey. Such mechanisms may greatly increase the efficiency of predation on bacteria and play a role in defining the habitat limitations of the flagellates.

Differences among bacterial strains as food for bacterivorous flagellates may have effects on in situ popu- lations of heterotrophic microflagellates. Sherr et al. (1983) demonstrated variation in growth rates, growth efficiencies and ammonium excretion for a species of Monas using 4 different bacterial prey. Studies which have estimated predation of growing or non-growing bacteria by flagellates (Kopylov et al., 1980; Fenchel, 1982b; Sherr et al., 1983; present study), even with different species of bacteria, have yielded generally similar ranges of predation rates, although the highest reported rates are from the present study. This suggests that predation rates may vary more due to variation of prey concentration and the species of flagellate being tested than due to the prey species.

Estimation of higher predation rates in the present study may in part be due to culture conditions and bacterial species used. Fenchel (1982a) has suggested that predation of bacteria by flagellates would increase with bacterial motility. The bacterium used in the present study was an actively growing and motile Vibrio. Fenchel (1982b) used a motile bacterial prey, but motility may have been affected since his experiments, as well as those of Sherr et al. (1983), were run under non-nutrient conditions. In addition, the predation rate estimates of these 2 studies both assume that the bacterial predation by flagellates and subsequent excretion do not result in undetected, 'cryptic', growth of the bacteria. Such 'cryptic' growth would result in an underestimation of predation rate. Alternatively, in the present study, if predation by flagellates affects the slope or relation of FDDC to growth rate, the estimated predation and clearance rates would be under- or overestimated depending upon the direction of the effect.

Estimated flagellate clearance rates in this study ranged from 0.17 to $3.36 \times 10^{-4} \mathrm{ml}$ flagellate $^{-1} \mathrm{~h}^{-1}$. Since clearance rates are a function of predation rates, these values also tend to be somewhat higher than the maximal clearance rates estimated by Fenchel (1982b) $\left(0.014\right.$ to $0.79 \times 10^{-4} \mathrm{ml} \mathrm{h}^{-1}$ flagellate $\left.{ }^{-1}\right)$ although the ranges overlap, and are higher than the clearance rates estimated by Sherr et al. (1983) ( 2 to $\left.9.5 \times 10^{-7} \mathrm{ml} \mathrm{h}^{-1}\right)$. Not unexpectedly, flagellate clearance rates tend to decrease with increasing prey density (Table 1; Fig. 3 and 4). Linear regression of this decrease with the log of bacterial concentration is highly significant $(\alpha=0.00003)$, although the variance remains large. Since predation rate is equal to clearance rate times bacterial concentration, clearance rate would be expected to decrease linearly with increasing log of bacterial concentration if predation rate increased linearly for the same values (Frost, 1972). Clearance rates for Narragansett Bay flagellates tend to be higher than those for Sargasso Sea flagellates at lower prey concentrations (less than $10^{6} \mathrm{ml}^{-1}$ ). This may be due in part to the experiments for the Narragansett Bay flagellates being run at lower bacterial concentrations, 
Table 1. Clearance rates $\left(\mathrm{ml}\right.$ flagellate $\left.\mathrm{h}^{-1} \mathrm{~h}^{-1} \times 10^{-4}\right)$ for Narragansett Bay and Sargasso Sea flagellates averaged for different ranges of bacterial concentrations

\begin{tabular}{|c|c|c|c|c|c|}
\hline \multirow[t]{2}{*}{ Flagellate species } & \multicolumn{5}{|c|}{ Bacterial concentration $\left(\times 10^{6} \mathrm{~m}^{-1}\right)$} \\
\hline & $<0.5$ & $0.5-1.0$ & $1.0-4.0$ & $4.0-7.5$ & $>7.5$ \\
\hline \multicolumn{6}{|l|}{ Narragansett Bay } \\
\hline Actinomonas mirabilis & - & - & 1.60 & 2.03 & - \\
\hline Monas sp. (1) & 0.633 & 0.624 & 0.137 & 0.145 & 0.263 \\
\hline Monas sp. (2) & 3.36 & 2.73 & 2.16 & - & 0.384 \\
\hline Paraphysomonas imperforata & 1.11 & 1.45 & 0.18 & 0.28 & - \\
\hline Bodo sp. & - & 1.20 & 0.50 & 0.19 & 0.32 \\
\hline Pseudobodo tremulans & 0.84 & 1.65 & 0.25 & 0.39 & - \\
\hline Acanthoeopsis unguiculata & - & - & 0.91 & - & - \\
\hline Weighted average & 1.36 & 1.65 & 0.91 & 0.26 & 0.33 \\
\hline \multicolumn{6}{|l|}{ Sargasso Sea } \\
\hline Pseudobodo tremulans (1) & - & 0.40 & 0.40 & 0.20 & 0.30 \\
\hline Pseudobodo tremulans (2) & - & - & 0.98 & 0.43 & 0.51 \\
\hline Monas sp. (3) & - & - & - & - & 0.20 \\
\hline Oikomonas sp. & - & 0.65 & 0.28 & 0.63 & 0.44 \\
\hline Bodo celer & - & - & - & 0.39 & - \\
\hline Rhynchomonas nasuta & - & - & 0.37 & 0.30 & 0.17 \\
\hline Bodo designis & - & - & 0.32 & 0.57 & 0.41 \\
\hline Weighted average & & 0.52 & 0.48 & 0.43 & 0.32 \\
\hline
\end{tabular}

rather than representing any real difference between oceanic and estuarine isolates. While clearance rates should theoretically decrease with the square of the cell diameter (Fenchel, 1982a), there was no such trend observed among the flagellates tested. The narrow range of flagellate sizes and variations in the predation mechanisms among the different strains and species of flagellates may account for this apparent lack of a relation.

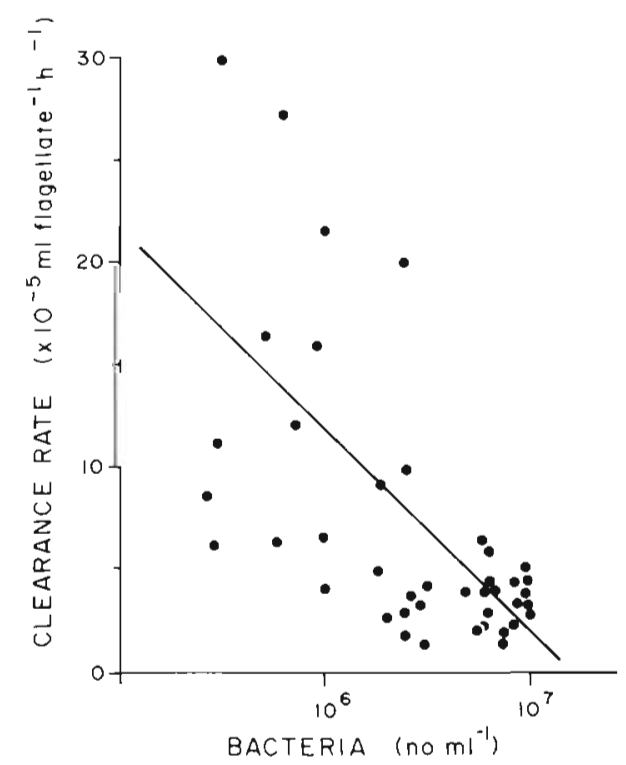

Fig. 4. Plot of clearance rates ( $\mathrm{ml}$ flagellate ${ }^{-1} \mathrm{~h}^{-1}$ ) for Narragansett Bay and Sargasso Sea flagellates vs. bacteria concentration ( $\log$ scale). Correlation coefficient $=-0.63$; significance of regression $=0.00003$

\section{ENVIRONMENTAL CONCENTRATIONS OF HETEROTROPHIC MICROFLAGELLATES}

Given these estimates of bacterial predation and clearance rates for heterotrophic microflagellates, it is possible to make some speculative estimates of the impact of these protozoans upon the bacterial populations in estuarine, shelf, and oligotrophic marine waters. As listed in Table 2, direct counts of heterotrophic nanoplankton (Davis and Sieburth, 1982) suggest flagellate populations of approximately $5 \times 10^{3}$, $3 \times 10^{3}$ and $0.5 \times 10^{3}$ organisms $\mathrm{ml}^{-1}$ for estuarine, shelf and Sargasso Sea, or Caribbean waters, respectively. Fenchel (1982c) reports similar flagellate populations for coastal waters. Bacterial populations are relatively constant for these same environments, being $2 \times 10^{6}, 1 \times 10^{6}$, and $0.5 \times 10^{6} \mathrm{ml}^{-1}$, respectively. Average flagellate predation rates on bacteria presented for these environmental concentrations of flagellates and bacteria would yield, on a population basis, a consumption rate of bacteria of $0.6 \times 10^{6}, 0.29 \times 10^{6}$, and $0.025 \times 10^{6}$ bacteria $\mathrm{ml}^{-1} \mathrm{~h}^{-1}$ for estuarine, shelf, and oceanic environments, respectively. Estimated bacterial volume per cell is approximately $60 \%$ lower for oceanic planktonic bacteria than the bacteria used in the present experiments. The slight decrease in the linear dimensions of the oceanic bacteria would be expected to decrease the rate of predation somewhat (Fenchel, 1982a). Also, assuming an accompanying decrease in prey energy content with lessened size, flagellate growth rates would be expected to decrease.

For environmental concentrations of bacteria, and 
Table 2. Average rates of flagellate predation and clearance for environmental concentrations of bacteria which are used to estimate bacterial growth rates for various marine environments

\begin{tabular}{|c|c|c|c|c|}
\hline & \multirow[t]{2}{*}{ Estuarine } & \multirow[t]{2}{*}{ Shelf } & \multicolumn{2}{|c|}{ Oceanic } \\
\hline & & & Water & Marine snow ${ }^{*}$ \\
\hline Bacteria populations $\left(\overline{\mathrm{x}} \mathrm{ml}^{-1}\right)$ & $2 \times 10^{6}$ & $1 \times 10^{6}$ & $0.5 \times 10^{6}$ & $1.0 \times 10^{7}$ \\
\hline Heterotrophic nanoplankton populations $\left(\overline{\mathrm{x}} \mathrm{ml}^{-1}\right)$ & $5 \times 10^{3}$ & $3 \times 10^{3}$ & $0.5 \times 10^{3}$ & $3.2 \times 10^{4}$ \\
\hline Predation rate $\left(\overline{\mathrm{x}}\right.$ bact flag $\left.^{-1} \mathrm{~h}^{-1}\right)$ & 121.0 & 96.2 & 50.0 & 210.1 \\
\hline Estimated bacteria consumed $\left(m l^{-1} h^{-1}\right)$ & $0.605 \times 10^{6}$ & $0.289 \times 10^{6}$ & $0.025 \times 10^{6}$ & $6.72 \times 10^{6}$ \\
\hline Estimated bacterial growth rate $\left(\mathrm{h}^{-1}\right)$ & 0.30 & 0.29 & 0.05 & 0.51 \\
\hline Estimated bacterial doubling time (h) & 2.3 & 2.4 & 13.9 & 1.3 \\
\hline Estimated clearance rate $\left(\mathrm{ml} \mathrm{h}^{-1}\right.$ flag $\left.^{-1}\right)$ & $6.05 \times 10^{-5}$ & $9.62 \times 10^{-5}$ & $1.0 \times 10^{-4}$ & $2.10 \times 10^{-5}$ \\
\hline Estimated No. ml cleared $\left(\mathrm{h}^{-1}\right)$ & 0.302 & 0.29 & 0.05 & 0.67 \\
\hline
\end{tabular}

assuming a balanced system in which bacterial growth equals bacterial predation, and that all bacterial death is due to flagellate predation, then one can estimate the bacterial growth rates shown in Table 2 which would be equivalent to bacterial doubling times of 2.3 , 2.4 and $13.9 \mathrm{~h}$ for estuarine, shelf, and oceanic environments, respectively. Clearance rates at this level of predation would suggest that $30 \%, 29 \%$ and $5 \%$ of the water is cleared per hour for the same environments, respectively. Environmental concentrations of bacteria are assumed not to represent thresholds below which flagellates do not or cannot feed. While not detected in this study, such thresholds may exist. Planktonic bacterial populations are very stable over the long term, but may vary temporally on a diel basis (Meyr-Reil, 1979; Johnson et al., 1983). Flagellate predation could possibly be induced by such changes and, therefore, be discontinuous. The estimated bacterial doubling times would be overestimated to the degree that in situ predation was less than estimated by these experiments.

Marine snow is a specialized microenvironment present in marine waters and the site of enriched bacterial and heterotrophic flagellate populations (Caron et al., 1982). Since several of the flagellates used in this study were isolated from marine snow in the Sargasso Sea, estimates of predation impact, clearance, and bacterial growth were made for these microenvironments. Approximately $6.7 \times 10^{6}$ bacteria could be consumed $\mathrm{ml}^{-1} \mathrm{~h}^{-1}$ equaling a bacterial doubling time of $1.3 \mathrm{~h}$ assuming that the system is in balance. Almost $1 \mathrm{ml}$ could be cleared by such flagellate populations per hour. However, this value is given with the caution that marine snow is in major part a surface environment and these estimates are made from rates determined for planktonic populations.

The preceding calculations all assume that the predation rate estimates for the cultured flagellates are representative of such rates for the populations of heterotrophic nanoplankton (Hnano) enumerated by epifluorescence microscopy, and that all of the Hnano are flagellates. Our data (Davis and Sieburth, 1983) suggest that 40 to $100 \%$ of cells in the Hnano are flagellates, and that they are morphologically similar to cultured forms. The appearance of bacteria in the food vacuoles of flagellates as observed by transmission electron microscopy (Sieburth and Davis, 1982; Johnson and Sieburth, unpubl.) and epifluorescence microscopy (Sherr and Sherr, 1983) suggests that these flagellates are bacterivorous, although this is difficult to establish for all of the flagellates. Bacterial growth rates estimated by these considerations significantly exceed estimates by other authors. As summarized by Sorokin (1978), marine bacterial growth rates have been estimated to range between 0.3 to $1.0 \mathrm{~d}^{-1}$ (equivalent to a doubling time of 17 to $55 \mathrm{~h}$ ). Using FDCgrowth rate relation, Hagström et al. (1979), Newell and Christian (1981), and Hanson et al. (1983) have estimated bacterial growth rates for nearshore and oceanic waters in the same range, but occasionally with doubling times less than $10 \mathrm{~h}$. Discrepancies between these bacterial growth rate estimates and those estimated in the present study may in part be reconciled if predation is not continuous throughout a diel cycle, but responsive to rapid increases in bacterial biomass resulting from pulsed phytoplankton release of zooplankton excretion of organic matter. While a cessation of feeding was not observed in the range of conditions of these experiments with the flagellate species used, it is possible that other uncultured species respond to threshold bacterial concentration in the marine plankton.

The results of this study indicate that apochlorotic microflagellates are capable of consuming actively growing bacteria at a range of environmental concentrations for both coastal and oceanic environments. Since populations of these micro-predators have been shown to be the most dominant protozoans in the 
marine plankton (Davis 1982; Davis and Sieburth, in prep.), both numerically and in biomass, it seems evident that these protozoans represent the dominant bacterivores in the mixed layer of the sea. The consumption of these flagellates by larger planktivores (Kopylov et al., 1981; D. Caron, pers. comm.) including the tintinnids (Verity, 1984) undoubtedly represents the final link in the transfer of bacterial biomass to the higher trophic levels.

Acknowledgements. The authors are grateful to P. W. Johnson, J. Knapp, and J. Millar Davis for aid in manuscript preparation and to N. Hairston Jr. and D. A. Caron for critical review; A. Hagström provided helpful suggestions with the FDC procedure. This work was supported by the Biological Oceanography Program of the National Science Foundation (Grant OCE-8121881).

\section{LITERATURE CITED}

Andrews, P., Williams, P. J. LeB. (1971). Heterotrophic utilization of dissolved organic compounds in the sea. III. Measurement of the oxidation rates and concentrations of glucose and amino acids in sea water. J. mar. biol. Ass. U. K. 51: 111-125

Azam, F., Hodson, R. E. (1977). Size distribution and activity of marine heterotrophs. Limnol. Oceanogr. 22: 492-501

Baxter, M., Sieburth, J. McN. (1984). Metabolic and ultrastructural response to glucose of two eurytrophic bacteria isolated from seawater at different enriching concentrations. Appl. environ. Microbiol. 47: 31-38

Beers, J. R., Reid, F. M. H., Stewart, G. L. (1975). Microplankton of the North Pacific Central Gyre. Population structure and abundance, June 1973. Int. Revue ges. Hydrobiol. 60 . $607-638$

Burney, C. M., Davis, P. G., Johnson, K. M., Sieburth, J. McN. (1981). Dependence of dissolved carbohydrate concentration upon small scale nanoplankton and bacterioplankton distributions in the western Sargasso Sea. Mar. Biol. 65: 289-296

Burney, C. M., Davis, P. G., Johnson, K. M., Sieburth, J. McN. (1982). Diel relationships of microbial trophic groups and in-situ dissolved carbohydrate dynamics in the Caribbean Sea. Mar. Biol. 67: 311-322

Caron, D. A., Davis, P. G., Madin, L. P., Sieburth, J. McN. (1982). Enrichment of heterotrophic bacteria and bacterivorous protozoa in oceanic macroaggregates. Science, N.Y. 218: 795-797

Christian, R. R., Hanson, R. B., Newell, S. Y. (1982). Comparison of methods for measurement of bacterial growth rates in mixed batch cultures. Appl. environ. Microbiol. 43: 1160-1165

Daggett, P., Nerad, T. A. (1982). Axenic cultivation of Bodo edax and Bodo ancinatus and some observations on feeding rate in monoxenic culture. Abstr. 30, J. Protozool. 29: 290-291

Davis, P. G. (1982). Bacterivorous flagellates in marine waters. Doctoral dissertation, University of Rhode Island, Kingston

Davis, R. G., Caron, D. A., Sieburth, J. McN. (1978). Oceanic amoebae from the North Atlantic: culture, distribution, and taxonomy. Trans. Am. microsc. Soc. 97: 73-88

Davis, P. G., Sieburth, J. McN. (1982). Differentiation of the phototrophic and heterotrophic nanoplankton populations in marine waters by epifluorescence microscopy. Annls Inst. océanogr., Monaco 58: 249-260

Davis, P. G., Sieburth, J. McN. (1983). Comparison of cultured and natural populations of heterotrophic microflagellates from estuarine and oceanic waters. J. Protozool. 30: 22A

Fenchel, T. (1980). Suspension feeding in ciliated protozoa: functional response and particle size selection. Microb. Ecol. 6: 1-11

Fenchel, T. (1982a). Ecology of heterotrophic microflagellates. I. Some important forms and their functional morphology. Mar. Ecol. Prog. Ser. 8: 211-223

Fenchel, T. (1982b). Ecology of heterotrophic microflagellates. II. Bioenergetics and growth. Mar. Ecol. Prog. Ser. 8: 225-231

Fenchel, T. (1982c). Ecology of heterotrophic microflagellates. IV. Quantitative occurrence and importance as bacterial consumers. Mar. Ecol. Prog. Ser. 9: 35-42

Frost, B. W. (1972). Effects of size and concentration of food particles on the feeding behavior of the marine planktonic copepod Calanus pacificus. Limnol. Oceanogr. 17: 805-815

Fuhrman, J. A., Azam, F. (1980). Bacterioplankton secondary production estimates for coastal waters of British Columbia, Antarctica, and California. Appl. environ. Microbiol. 39: 1085-1095

Fuhrman, J. A., Azam, F. (1982). Thymidine incorporation as a measure of heterotrophic bacterioplankton production in marine surface water: evaluation and field results. Mar. Biol. 66: 109-120

Haas, L. W., Webb, K. L. (1979). Nutritional mode of several non-pigmented microflagellates from the York River estuary, Virginia. J. exp. mar. Biol. Ecol. 39: 125-134

Hagström, A., Larsson, U., Horstedt, P., Normark, S. (1979). Frequency of dividing cells, a new approach to the determination of bacterial growth rates in aquatic environments. Appl. environ. Microbiol. 37: 805-812

Hanson, R. B., Shafer, D., Ryan, T., Pope, D. H., Lowery, H. K. (1983). Bacterioplankton in Antarctic ocean waters during late austral winter: abundance, frequency of dividing cells, and estimates of production. Appl environ. Microbiol. 45: 1622-1632

Hobbie, J. E., Rublee, P. (1977). Radioisotope studies of heterotrophic bacteria in aquatic ecosystems. In: Cairns, J. (ed.) Aquatic microbial communities. Garland Publ. Co., New York, p. 441-476

Johnson, K. M., Davis, P. G., Sieburth, J. McN. (1983). Diel variation of $\mathrm{TCO}_{2}$ in the upper layer of oceanic waters reflects microbial composition, variation, and possibly methane cycling. Mar. Biol. 77: 1-10

Johnson, P. W., Sieburth, J. McN. (1979). Chroococcoid cyanobacteria in the sea: a ubiquitous and diverse phototrophic biomass. Limnol. Oceanogr. 24: 928-935

King, K. R., Hollibaugh, J. T., Azam, F. (1980). Predator-prey interactions between a larvacean Oikopleura dioica and bacterioplankton in enclosed water columns. Mar. Biol. 56: 49-57

Kopylov, A. I., Mamayeva, T. I., Batsanin, S. F. (1980). Energy balance of the colorless flagellate Parabodo attenuatus (Zoomastigophora, Protozoa). Oceanology 20: 705-708

Kopylov, A. I., Moiseyev, E. S. (1980). Effect of colorless flagellates on the determination of bacterial production in seawater. Dokl. Akad. Nauk SSSR Biol. Sci. 252: 272-274

Kopylov, A. I., Pasternak, A. F., Moiseyev, Ye. V. (1981). Consumption of zooflagellates by planktonic organisms. Oceanology 21: 269-271

Larsson, U., Hagström, A. (1982). Fractionated phytoplankton primary production, exudate release and bacterial produc- 
tion in a Baltic eutrophication gradient. Mar. Biol. 67: $57-70$

McDuff, R. E., Chisholm, S. W. (1982). The calculation of in situ growth rates of phytoplankton populations from fractions of cells undergoing mitosis: a clarification. Limnol. Oceanogr. 27: 783-788

Meyer-Reil, L.-A., Dawson, R., Liebezeit, G., Tiedge, H. (1979). Short term variation in microbiological and chemical parameters. Mar. Ecol. Prog. Ser. 1: 1-6

Newell, S. Y., Christian, R. R. (1981). Frequency of dividing cells as an estimator of bacterial productivity. Appl. environ. Microbiol. 42: 23-31

Porter, K. G., Feig, Y. S. (1980). The use of DAPI for identifying and counting aquatic microflora. Limnol. Oceanogr. 25: 943-948

Sherr, E. B., Sherr, B. F. (1983). Double-staining epifluorescence technique to assess frequency of dividing cells and bacteriovory in natural populations of heterotrophic microprotozoa. Appl. environ. Microbiol. 46: 1388-1393

Sherr, B. F., Sherr, E. B., Berman, T. (1982). Decomposition of organic detritus: a selective role for microflagellate protozoa. Limnol. Oceanogr, 27: 765-769
Sherr, B. F., Sherr, E. B., Berman, T. (1983). Growth, grazing, and ammonia excretion rates of a heterotrophic microflagellate fed with four species of bacteria. Appl. environ. Microbial. 45: 1196-1201

Sieburth, J. McN. (1979). Sea microbes. Oxford University Press, New York

Sieburth, J. McN., Davis, P. G. (1982). The role of heterotrophic nanoplankton in the grazing and nurturing of planktonic bacteria in the Sargasso and Caribbean Seas. Annls Inst. océanogr., Monaco 58S: 285-296

Sieburth, J. McN., Johnson, P. W., Eberhardt, M. A., Sieracki, M. E. (1984). Methane-oxidizing bacteria from the mixing layer of the Sargasso Sea and their photosensitivity. Trans. Am. Geophys. Union 64: 1054

Sorokin, Y. I. (1978). Decomposition of organic matter and nutrient regeneration. In: Kinne, O. (ed.) Marine ecology, Vol. IV, Dynamics. John Wiley \& Sons, Chichester, p. $501-616$

Verity, P. G. (1984). The physiology and ecology of tintinnids in Narragansett Bay, Rhode Island. Ph. D. dissertation, University of Rhode Island, Kingston, Rhode Island

This paper was submitted to the editor; it was accepted for printing on May 26, 1984 